\title{
Genomes take pole position in the icy wastes
}

Hannah Hoag, Washington

Our knowledge of the Arctic and Antarctic has been transformed since the first successful expeditions to the poles nearly a century ago. Now, the US National Academy of Sciences has mapped out its strategy for advancing our understanding of these inhospitable regions further. Its report, which was released on 7 February, puts genomic sequencing firmly at the centre of this endeavour.

The report's authors say that the National Science Foundation (NSF) should establish a Polar Genome Science Initiative to understand, at the genomic level, polar organisms and how they interact with the environment. Possible benefits of such a project include fresh perspectives on the mechanisms of evolutionary adaptation, and the potential to uncover potentially useful genes.

The NSF is currently studying the report's recommendations. "We are excited by this," says Karl Erb, director of the foundation's Office of Polar Programs. "These really are new frontiers."

Polar research has so far lacked a genomics component, says William Mohn, a microbiologist at the University of British Columbia in Vancouver, Canada, who helped to prepare the report. "In the past, people have been doing physiological studies but they now need genomic information to do cutting-edge research," he says.

The report recommends that the NSF makes it a priority to assess which polar organisms are best suited to a wide range of scientific studies, and so should be selected for analysis. It also argues that non-polar researchers with expertise in genomics should be invited to participate in the project, and that international collaborations should be set up.

The results of a polar genomics initiative would be interesting, predicts William Detrich, a marine biologist at Northwestern University in Boston who chaired the committee that prepared the report. The polar regions offer unique opportunities to study evolution, he says, because of the way in which different organisms have adapted to the area's extreme conditions. Understanding this evolution could aid predictions of the impact that climate change will have on the region. Some fish, for example, have lost the ability to survive at temperatures above $4^{\circ} \mathrm{C}$.

The pay-offs might be even broader. The genes for molecules that allow polar organisms to survive low temperatures could, for example, be introduced into plants, increasing the amount of the world's land that is available for farming. Researchers also believe that some proteins produced by krill, shrimp-like creatures that live in polar seas, could find applications in food processing

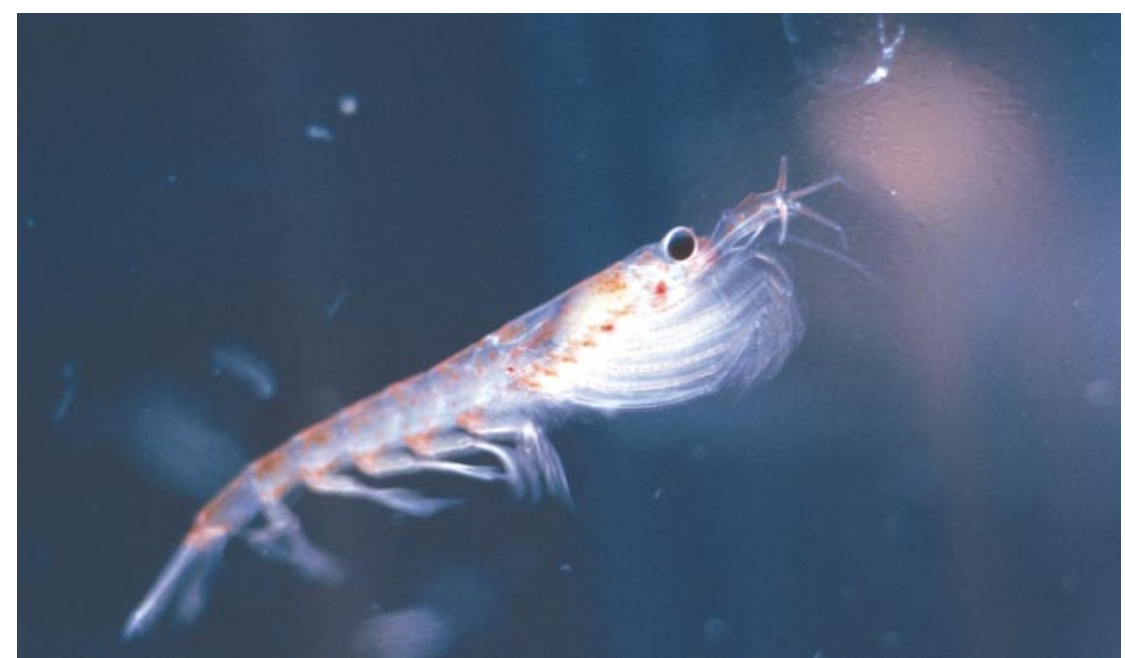

In from the cold: krill are one of the polar organisms that may have their genome sequenced.

and storage. But before such applications can be developed, researchers must reveal the expression and function of the prospective genes and proteins.

To achieve this, better facilities will be needed. Limited equipment, poor infrastructure and disjointed Arctic and Antarctic programmes have impeded research, say the report's authors. They suggest establishing a 'freezer farm' somewhere in the United States so that researchers can gain access to polar organisms for pilot studies without having to journey to the poles. Detrich adds that polar researchers need better access to high-throughput sequencing facilities. The report suggests creating a virtual sequencing centre that would negotiate access to existing centres.

\section{Canada boosts spending on science}

\section{David Spurgeon, Montreal}

The farewell budget from Canadian Prime Minister Jean Chrétien, announced on 18 February, contains substantial spending hikes in many areas, including science.

As Chrétien enters his final year in government, Canada is the only country in the group of seven leading economic powers that is expected to record a surplus in 2002-03 - and most of that surplus will be spent in the new budget.

Research will benefit from a $10 \%$ increase - worth Can\$125 million (US\$84 million) - in the annual budget for the country's three federal granting councils, which allocate funding to university researchers. A further Can $\$ 225$ million will go to universities, colleges and research hospitals annually to help support this and other new research.

Part of this extra money will be channelled into the Polar Continental Shelf Project, which is responsible for providing infrastructure support for Arctic researchers. It will get a further Can\$6 million over the next two years. Polar researchers warned last month that this programme would disappear without a cash injection (see Nature 421, 464; 2003). Other federal projects in the Arctic will get Can $\$ 10$ million over the next two years.

Chrétien has also boosted environmental technology. Canada ratified the Kyoto Protocol, the international agreement on limiting greenhouse-gas emissions, on 17 December, and the budget includes Can $\$ 2$ billion to help implement the government's plans on climate change.

But the wide variety of projects to be funded with this money, ranging from energy efficiency in buildings to fuel-cell projects, has left some observers fearful that infighting between government departments could dilute the impact of the new money. "We find the lack of detail very disconcerting," says John Bennett of the Sierra Club of Canada, an Ottawa-based environmental group.

A new programme will raise the number of government graduate scholarships by $70 \%$ to 10,000 by 2007 . Administered by the granting councils, the scheme will support 2,000 masters and 2,000 doctoral students with annual awards of Can\$17,500 and Can\$35,000, respectively. www.fin.gc.ca/budtoce/2003/budliste.htm 